\title{
Laboratorium Experimental Of Cantilever Sheet Pile Behaviour On Soft Soil Induced By Strip Load
}

\author{
Ichsan Rauf $^{1^{*}}$, Tri Hrianto ${ }^{2}$, and Kusnadi ${ }^{1}$ \\ ${ }^{1}$ Civil Engineering Departement, Khairun University, Ternate, Indonesia \\ ${ }^{2}$ Civil Engineering Departement, Hasanuddin University, Makassar, Indonesia
}

\begin{abstract}
This study aims to analyze the deflection behavior of the sheet pile through experimental testing and numerical analysis using the Finite Element Method (FEM). The Laboratorium scale test on a Tub with length of $1500 \mathrm{~mm}$, width of $600 \mathrm{~mm}$, and height of 1500 $\mathrm{mm}$, and Steel Plate $3.2 \mathrm{~mm}$ with dimensions of $1400 \mathrm{~mm} \times 590 \mathrm{~mm}$ was used as a model of the sheet pile wall. The subgrade material is clay soil and embankment material in the form of Sirtu which passes the No. sieve. 40. Physical and mechanical testing of soil and gravel materials is carried out with reference to ASTM standards. The measurement of the value of the strip load (q) and deflection was carried out using a load cell with a capacity of $100 \mathrm{kN}$ and a linear variable differential transformer (LVDT). The deflection of the sheet pile was using was analyzed using Plaxis 8.2 software of the FEM method. The results of laboratory tests show that the pile wall collapses at a load of $74 \mathrm{kN} / \mathrm{m} 2$, with a deflection of $24.56 \mathrm{~mm}$, while the FEM analysis shows that the pile wall collapses at a load of $71 \mathrm{kN} / \mathrm{m} 2$ with a deflection of $21.29 \mathrm{~mm}$.
\end{abstract}

Keywords: Deflection, Sheet pile, Strip load, FEM.

\section{Introduction}

The retaining structure is generally applied in the land expansion works in steep areas, reclamation works in coastal and port areas, supporting soil in basement excavation work, and abutment structures on bridges. In principle, this structure aims to withstand the lateral forces acting behind it. Therefore, as a geotechnical system, this structure will not fail or collapse under any load that may occur, such as static and dynamic loads, fluid pressure, and seepage [1].

Retaining structures can generally be grouped based on three factors, namely gravity, flexibility, and mechanical stabilization of soil walls. Sheet pile walls are a flexible type of slope reinforcement that has advantages in terms of fast construction, lightweight, high resistance to driving pressure, and long service life for conditions above and below the water surface [2]. This technical advantage then encourages the use of sheet pile walls in various constructions with many types of constituent materials, such as wood, concrete, and steel.

Related to the working principle, the sheet pile walls work by relying on the stiffness of the constituent material and the balance of the passive pressure of the soil. Changes in pressure that occur behind the sheet pile walls due to external loads, such as building construction or vehicles, will increase the lateral pressure along the sheet pile walls. This has the potential to cause horizontal movements (deflection) and settlements which become two main factors in designing the stability in sheet pile walls [3].

Lateral displacement of retaining walls is an important consideration in evaluating the impact on adjacent structures. In addition, the allowable displacement of the walls depends on soil conditions, location of adjacent structures of retaining walls, existing conditions and type of building foundation, and others [4]. Therefore, an understanding of the behavior and prediction of the deflection of the sheet pile wall due to the loading that occurs is very important in planning the stability of the structure design of sheet pile walls.

Many studies related to the deflection behavior of sheet pile walls have been carried out, such as deflection due to the excavation process or deflection of anchored sheet piles. However, the deflection behavior of the cantilever sheet pile due to load is still very limited. For this reason, the focus of this study is to analyze the relationship between the horizontal movement of the sheet pile walls caused by the load acting on the sandy embankment. Understanding this relationship is highly important for geotechnical planners in designing load-

\footnotetext{
* Corresponding author: ichsan rauf@unkhair.ac.id
} 
bearing sheet pile walls that will work behind the sheet pile so that the resulting design will be more economical.

\section{Methods}

\subsection{Experimental Setup}

This study applied a laboratory experiment to analyze the effect of strip load on the deflection of the sheet pile walls using a test bath with a length of $1500 \mathrm{~mm}$, a width of $600 \mathrm{~mm}$, and a height of $1400 \mathrm{~mm}$. For the sheet pile model, the researchers used a steel plate with a thickness of $3.2 \mathrm{~mm}$, a length of $1400 \mathrm{~mm}$, and a width of 590 $\mathrm{mm}$. Static loading was carried out using a hydraulic pump placed on a steel plate with dimensions of $500 \mathrm{~mm}$ x $400 \mathrm{~mm}$ x $20 \mathrm{~mm}$ and positioned on $200 \mathrm{~mm}$ from the sheet pile wall. The overall test model schematic applied in the study is shown in Figure 1.

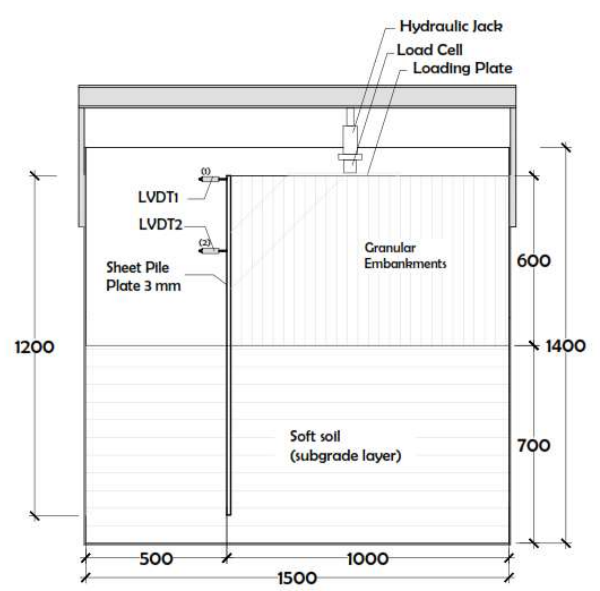

Fig.1. Laboratory experimental model

For the soil layer, the researchers used clay as the subgrade with a thickness of $700 \mathrm{~mm}$, a free sheet pile height $(\mathrm{H})$ of $600 \mathrm{~mm}$, and an embedded depth (D) of $600 \mathrm{~mm}$. The compaction process was carried out in stages by dividing the thickness of this layer into 3 layers with a thickness of $250 \mathrm{~mm}$ each. The static compaction method was conducted using steel plates until the thickness of each layer met the density value of the laboratory test results. In addition, sand cone testing was carried out on each layer as a control to the density value intended to be achieved.

For the embankment material, the researchers used granular material. In this study, the researchers specifically chose sandstone material that passed sieve No 40. Testing of physical properties, mechanical properties, and material preparation for the base material in the form of clay, sand, and soil embankments is referred to in the ASTM standard. In addition, the stiffness of the steel plate used as the cantilever sheet pile was also analyzed based on the results of the tensile test.

The implementation of the physical model test of the sheet pile wall deflection is shown in Figure 2. The measurement of the value of the deflection and deformation that occurred was carried out using a Linear Variable Differential Transformer (LVDT) which was positioned at the free end of the sheet pile $\left(\mathrm{H}_{1}\right)$ and the center of the sheet pile $\left(\mathrm{H}_{2}\right)$. Meanwhile, the measurement of the value of static load was conducted using a load cell with a capacity of $100 \mathrm{kN}$. These two measuring devices were connected to a data logger to record the values of the load that occurred and the horizontal displacement, in which the static loading was carried out with a hydraulic jack until the model collapsed.

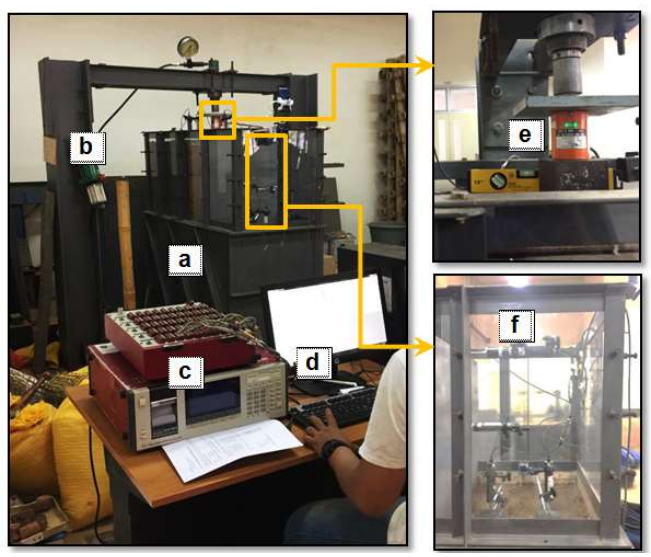

Fig.2. Experimental setup: (a) steel tank, (b) hydraulic jack, (c) data logger, (d) computer unit, (e) LVDT, and (f) load cell with a capacity of $100 \mathrm{kN}$

\subsection{Finite Element Model (FEM) Analysis with PLAXIS}

The numerical analysis approach in this study was carried out as a verification of the results of the laboratory test model and to understand the deformation and deflection that occurred in the soil mass. In this study, the researchers used PLAXIS Version 8.6 with a license from the Faculty of Engineering, Hasanuddin University.

The geometry model in PLAXIS was the same as the laboratory model (a model length $1500 \mathrm{~mm}$ and a model height of $1500 \mathrm{~mm}$ ), in which the analysis model used was Plane Strain Analysis. The finite model condition was assumed that the vertical finite was free vertically and constrained horizontally, while the lower horizontal finite was fully fixed.

The soil failure modeling was assumed to follow the Mohr-Coulomb model. Meanwhile, the applied steel plate model was elastic, in which the interface of each material used was obtained from the test results of the physical and mechanical parameters of the material on a laboratory scale. For the loading analysis, the model given loading until reaching the failure limit was set at the construction stage with an increase in the load interval of $10 \mathrm{kN}$. 


\section{Results and Discussion}

\subsection{Physical and Mechanical Properties of Materials Used}

The results of the test of the clay material used in the study, as shown in Table 1, indicate that the type of material is clay with weak consistency. From the mapping of soil types referring to the ASTM D2487 standard, the soil samples in this study can be classified as sandy fat clay with high plasticity $(\mathrm{CH}$, sandy fat clay). Meanwhile, based on the Casagrande chart, as shown in Figure 3, by plotting the plasticity index (PI) value of $29.29 \%$ and the liquid limit value of $58.37 \%$, the soil sample is classified as an inorganic soil with high plasticity. The results of this physical property test are in line with the results of mechanical tests which show a density value of $14.12 \mathrm{kN} / \mathrm{m}^{3}$ and a free compressive strength value $\left(\mathrm{q}_{\mathrm{u}}\right)$ of $5.71 \mathrm{kN} / \mathrm{m}^{2}$, indicating that the clay material has a soft consistency.

Table 1. Physical and mechanical properties of soft soil

\begin{tabular}{|c|c|c|c|}
\hline No & Soil Properties & Unit & Result \\
\hline 1 & Specific Gravity (Gs) & - & 2.71 \\
\hline \multirow[t]{2}{*}{2} & Sieve Analysis & & \\
\hline & a. Sand & $\%$ & 31.60 \\
\hline \multirow[t]{2}{*}{3} & b. Silt & $\%$ & 19.28 \\
\hline & c. Clay & $\%$ & 49.12 \\
\hline \multirow[t]{5}{*}{4} & Atterberg Limit & & \\
\hline & a. Liquid Limit (LL) & $\%$ & 58.37 \\
\hline & b. Plasticity Limit (PL) & $\%$ & 29.08 \\
\hline & c. Plasticity Index (PI) & $\%$ & 29.29 \\
\hline & d. Shrinkage Limit (SL) & $\%$ & 20.16 \\
\hline 5 & Dry Density $(\gamma d)$ & $\mathrm{kN} / \mathrm{m}^{3}$ & 14.12 \\
\hline 6 & $\begin{array}{l}\text { Optimum Water Content } \\
\text { (w) }\end{array}$ & $\%$ & 32.39 \\
\hline 7 & $\begin{array}{l}\text { Unconfined compression } \\
\text { strength }\left(\mathrm{q}_{\mathrm{u}}\right)\end{array}$ & $\mathrm{kN} / \mathrm{m}^{2}$ & 5.71 \\
\hline 8 & Cohesion $(\mathrm{c})$ & $\mathrm{kN} / \mathrm{m}$ & 16.52 \\
\hline 9 & Shear Angle $(\phi)$ & $\circ$ & 22.21 \\
\hline
\end{tabular}

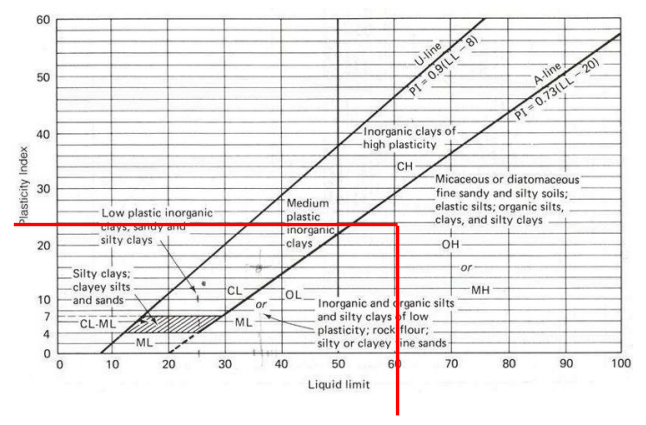

Fig.3. Soft soil classification based on USCS

The embankment material used in this study was sandstone which passed a $19 \mathrm{~mm}$ sieve. The results of mechanical testing of the sandstone embankment material showed a dry density $\left(\gamma_{\text {dry }}\right)$ of $20.08 \mathrm{kN} / \mathrm{m}^{3}$ at an optimum moisture content of $7.57 \%$. In the implementation of field compaction, the maximum laboratory density condition was highly difficult to fulfill [5]. Therefore, for the implementation of model testing, the density value of the sandstone chosen was $90-95 \%$ of the optimum density for the wet side. Thus, the applied gravel material with a density value of $95 \%$ $\left(\gamma_{95}\right)$ was $19.08 \mathrm{kN} / \mathrm{m}^{3}$. From the sampling of compacted soil in the test model, a direct shear test was carried out and the gained cohesion (c) value of the sandstone was $8.2 \mathrm{kN} / \mathrm{m}^{2}$ with a shear angle $(\phi)$ of $38^{\circ}$. Yield stress (fy) and modulus of elasticity (E) of steel sheet pile based on tensile test results were $266.635 \mathrm{MPa}$ and $190.859 \mathrm{MPa}$, respectively. For the steel plate thickness of $3.2 \mathrm{~mm}$, the obtained EI value was $0.44 \mathrm{kN} / \mathrm{m}^{2} / \mathrm{m}^{\prime}$ and the obtained EA value was $5.92 \mathrm{kN} / \mathrm{m}$ '.

\subsection{Deflection of Sheet Steel Pile}

The results of this experiment indicate that the loading on the embankment will provide additional stresses around the sheet pile walls. This results in the movement of both the sheet pile and the embankment soil, as shown in Figure 4a. In addition, the relationship of the value of the concentrated load $(\mathrm{P})$ and the deflection is shown in Figure $4 \mathrm{~b}$. By converting the load into a uniform load by dividing the value of $\mathrm{P}$ by the area of the load plate, it obtained the working load of $74.63 \mathrm{kN} / \mathrm{m}^{2}$ and the deflection of the sheet pile walls at LVDT 1 and LVDT 2 of $24.07 \mathrm{~mm}$ and 12.14 , respectively.
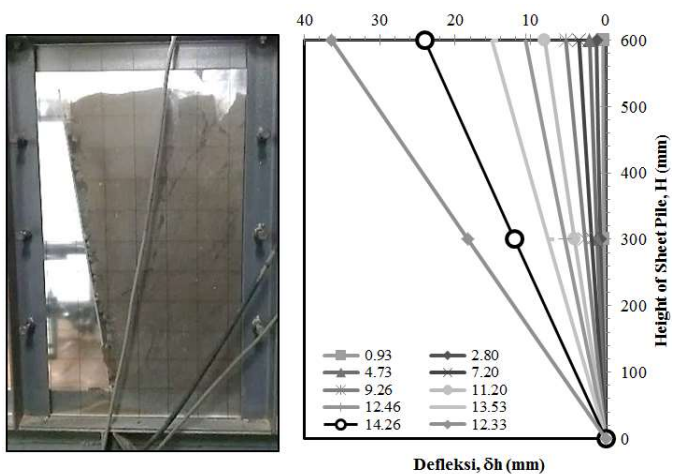

Fig.4. Deflection on sheet pile: (a) failure mode on sheet pile after loading and (b) deflection on top (LVDT1) and middle (LVDT2) of sheet pile

The behavior of the load on the horizontal displacement of the sheet pile is expressed as a normalized number which is the ratio of the horizontal displacement value of the sheet pile $\left(\delta_{\mathrm{h}}\right)$ to the free height of the sheet pile wall $(\mathrm{H})$. At the beginning of the loading, it was seen that the wall deflection that occurred was very small until it reached the load limit of $48.47 \mathrm{kN} / \mathrm{m}^{2}$ with a $\delta \mathrm{h} / \mathrm{H}$ ratio of $0.9 \%$. After exceeding the load of $48.47 \mathrm{kN} / \mathrm{m}^{2}$, the increase in the deflection of the sheet pile was seen to be more significant as the load increased until it reached failure with a $\delta \mathrm{h} / \mathrm{H}$ ratio of $4.01 \%$.

The failure pattern of the triangular cantilever sheet pile system, as shown in Figure 4a, explains that the stress distribution in the embankment layer is in line with Boussinesq's theory. As a result of this loading, the lateral pressure that occurs reduces the density of the 
embankment material around the load [6], causing horizontal movement in the cantilever sheet pile system.

Figure 5 shows the relationship between the load value and the deflection value with a parabolic curve, indicating that the distribution of lateral pressure due to the load along the sheet pile tends to be non-linear [7]. By referring to the Australian Standard AS 5100, it requires that the design life of the sheet pile walls is 100 years with a maximum deflection criterion of $1 \%$ of the free pile height. Meanwhile, several studies have shown that the maximum horizontal displacement value in sandy embankments is generally less than $0.5 \% \mathrm{H}$ [8], [9]. Meanwhile, if the embankment material is sandy loam, the maximum deflection is $0.33 \% \mathrm{H}$ [10].

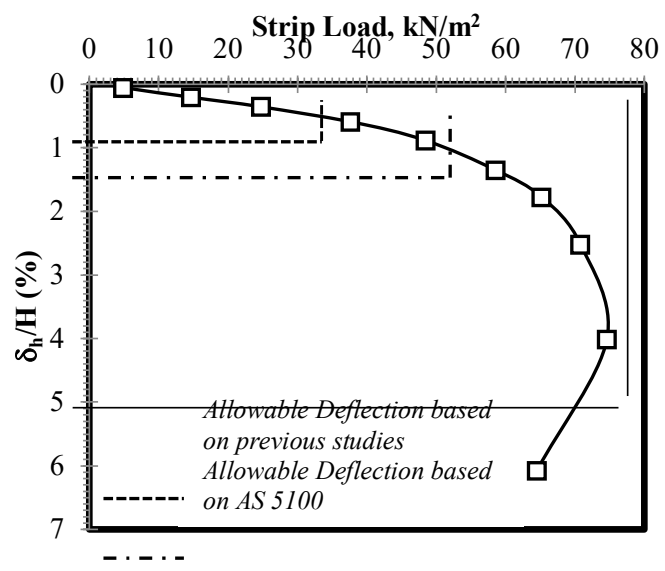

Fig.5. The effect of strip load on deflection ratio

By using the graphical approach, the maximum allowable load that can be given for this research model can be determined. Referring to the standards and results of previous studies, the allowable load on the embankment is $51 \mathrm{kN} / \mathrm{m}^{2}$ for the $1 \%$ deflection limit. Meanwhile, for the $0.5 \%$ deflection limit, the maximum load is $34 \mathrm{kN} / \mathrm{m}^{2}$. In other words, the acceptable allowable load is $48 \%$ qult and $68 \%$ qult.

\subsection{Numerical Analysis with PLAXIS}

In this study, the results of the physical model testing were then compared with numerical analysis using the finite element model (FEM). In addition, the researchers utilized PLAXIS 2D Version 8.5 with a license from the Environmental Geotechnical Laboratory of Hasanuddin University.

The constitutive model of the simulation in PLAXIS was made the same as the model in the laboratory test, as shown in Figure 6, in which the horizontal side is joints, while the vertical side is the roller that allows horizontal movement. The results of the laboratory test from the physical and mechanical parameters of the materials used are input parameters for material interfaces in PLAXIS, consisting of subgrade materials, sandstones, and sheet pile walls. These parameters are shown in Table 2.
Table 2. Mechanical properties of materials used in FEM analysis

\begin{tabular}{|c|c|c|c|}
\hline Materials & Subgrade & $\begin{array}{c}\text { Coarse } \\
\text { Aggregate }\end{array}$ & $\begin{array}{l}\text { Sheet } \\
\text { Piles }\end{array}$ \\
\hline Model Material & $\begin{array}{l}\text { Mohr- } \\
\text { Coulomb }\end{array}$ & $\begin{array}{c}\text { Mohr- } \\
\text { Coulomb }\end{array}$ & - \\
\hline Material Type & Undrained & Drained & Elastic \\
\hline$\gamma_{\mathrm{sat}}, \mathrm{kN} / \mathrm{m}^{3}$ & 15.68 & 20 & - \\
\hline$\gamma_{\text {unsat }}, \mathrm{kN} / \mathrm{m}^{3}$ & 14.12 & 19 & - \\
\hline E ref, $\mathrm{kN} / \mathrm{m}^{2}$ & 4884 & 13600 & - \\
\hline Poisson Ratio, v & 0.35 & 0.30 & 0.2 \\
\hline $\begin{array}{l}\text { Cohesion (c, } \\
\left.\mathrm{kN} / \mathrm{m}^{2}\right)\end{array}$ & 16.52 & 8.00 & - \\
\hline Shear Angle $\left(\phi,{ }^{\circ}\right)$ & 26.25 & 38.00 & - \\
\hline $\mathrm{EA}, \mathrm{kN} / \mathrm{m}$ & - & - & $6.40 \mathrm{E}+05$ \\
\hline $\mathrm{EI}, \mathrm{kNm}^{2} / \mathrm{m}$ & - & - & 0.546 \\
\hline
\end{tabular}

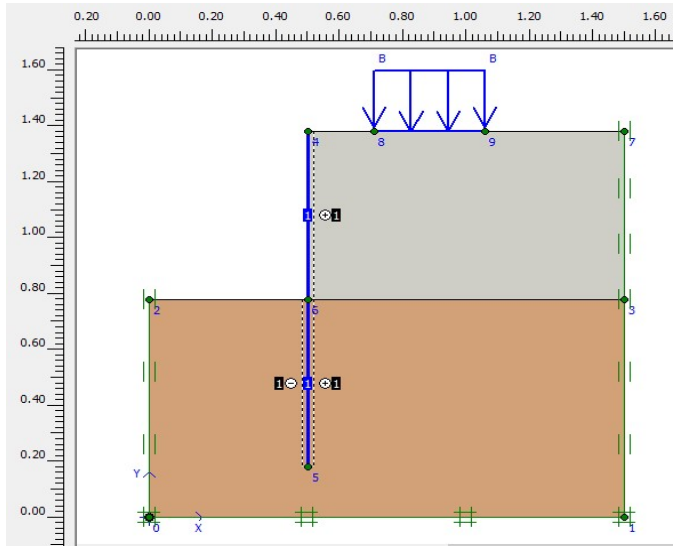

Fig.6. Simulation model on PLAXIS 8.5

The results of modeling the horizontal movement of the sheet pile with PLAXIS show that the sheet pile failure tends to be similar to the results obtained in the laboratory model (Figure 7a). However, the results of this simulation indicate that the sheet pile wall collapses at a peak load of $71 \mathrm{kN} / \mathrm{m}^{2}$ with a maximum deflection value of $21.29 \mathrm{~mm}$. Meanwhile, Figure $7 \mathrm{~b}$ reflects the distribution of the deflections that occur along with the free sheet pile.

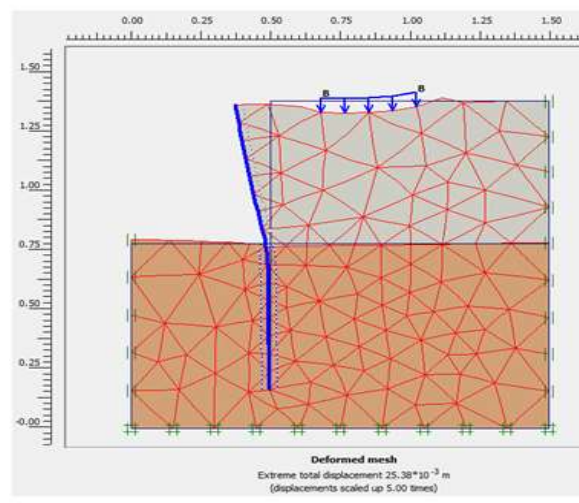

(a) 


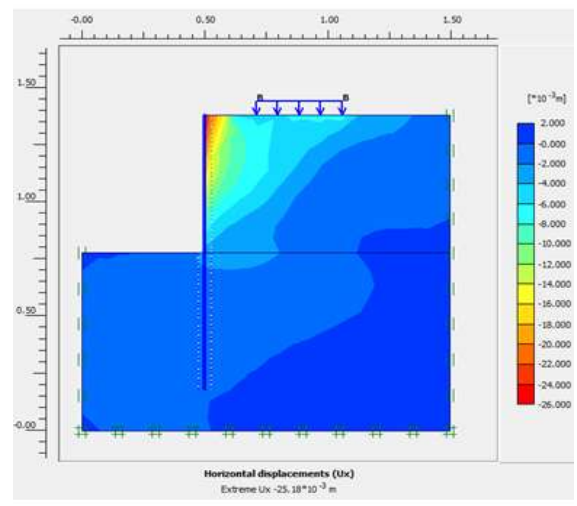

(b)

Fig.7. Simulation results of horizontal displacement on sheet pile by using PLAXIS on peak load: (a) failure mesh model of sheet pile and (b) distribution of horizontal displacement on sheet pile

The relationship between strip load and pile wall deflection in laboratory testing and FEM analysis is presented in Figure 8. In general, it can be seen that the FEM and laboratory analyzes have the same tendency. However, the limit of the FEM simulation results gives a smaller load and deflection value compared to the laboratory scale test with a deviation of $4.86 \%$ for a peak load of $11.58 \%$ for deflection. This difference is presumed due to limitations in laboratory testing.

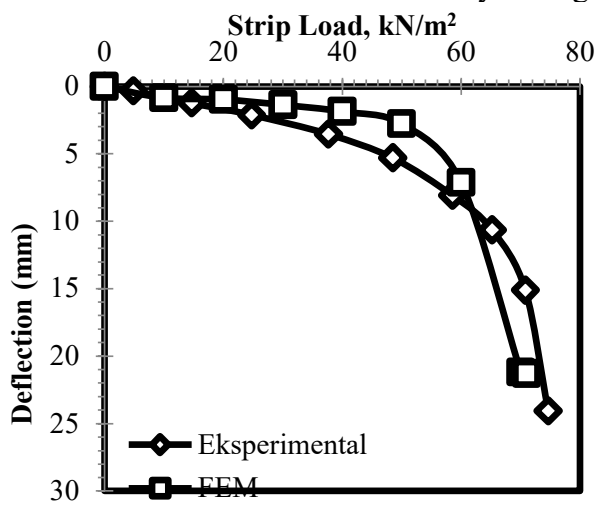

Fig.8. The results of the comparison between laboratory model testing and FEM analysis

\section{Conclusions}

This study provides information regarding the interaction between the strip load acting on the embankment soil and the deflection behavior of the sheet pile walls. Based on the results of this study, it can be concluded as follows.

1. The sheet pile failure occurred at a uniform load of $74 \mathrm{kN} / \mathrm{m}^{2}$ with a deflection value of $24.56 \mathrm{~mm}$. If referring to the required allowable deflection value according to previous studies and AS Standard 5100, the maximum load values that can be given are 34 $\mathrm{kN} / \mathrm{m}^{2}$ and $51 \mathrm{kN} / \mathrm{m}^{2}$.
2. Comparison of simulation results with PLAXIS gives smaller values for both loading and deflection values than laboratory tests with deviations of $4.86 \%$ and $11.58 \%$, respectively.

\section{References}

[1] M. Budhu, Soil Mechanics and Foundations, 3rd ed., Danver, USA: John Wiley \& Sons, Inc. , (2010).

[2] A. Holakoo, R. Weeraratne and K. Kugathasan, "Sheet Pile Retaining Walls - Design and Construction in a Brown Fields Environment," Sydney, (2017).

[3] A. P. Singh and K. Chatterjee, "Ground Settlement and Deflection Response of Cantilever Sheet Pile Wall Subjected to Surcharge Loading," Indian Geot. J., vol. 50, pp. 540-549, (2020).

[4] P. Fok, B. Hong Neo, C. Veeresh, D. Wen and K. H. Goh, "Limiting values of retaining wall displacements and impact to the adjacent structures," The IES Journal Part A: Civil \& Structural Engineering, vol. 5, no. 3, pp. 134-139, (2012).

[5] J. P. R. Guayer, An Introduction to Foundations on Fill and Backfilling, New York: Continuing Education and Development, Inc., (2013).

[6] Aparna and N. K. Samadhiya, "Evaluation of Model Sheet Pile Wall Adjacent to A Strip Footing - An Experimental Investigation," Inter. J. Of Geo. Eng, pp. 1-9, (2019).

[7] Z.-w. Deng, X.-1. Liu and W.-m. Leng, "Spatial Soil Pressure Test and Calculation Analysis of Sheet-pile Wall," Applied Mechanics and Materials, Vols. 105-107, pp. 1040-1047, (2012).

[8] G. W. Clough and T. D. O.Rourke, "Construction Induced Movements on Insitu Walls," Earth Retaining Structure, pp. 439-470, (1990).

[9] H. S. Hsieh, C. Wang and C. Y. Ou, "Use of Jet Grouting to Limit Diaphragm Wall Displacement of a Deep Excavation," Geotechnical an Geoenvirontment Engineering, ASCE, vol. 129, no. 52, pp. 146-157, (2003).

[10] J. Oliveira, M. Marques, D. Cabral, M. Silva and L. Caneiro, "Horizontal Displacements in Daphragm Wall," 5th Brazilian Conference on Slope Stability, vol. 1, pp. 245-250, (2009). 